\title{
Stochastic Wind Loading Applied to Container Crane
}

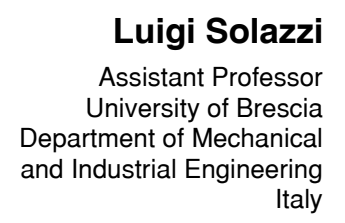

Luigi Solazzi

Assistant Professo Department of Mechanical Italy

This paper describes the research on the mechanical behavior of a container crane subjected to variable wind loading.

In the first step the wind action was studied and defined. Stochastic wind loading was simulated by means of power spectrum method.

Preliminary analyses were carried out on a chimney $(100 \mathrm{~m})$ because its geometry is very simple. Many different schematizations were implemented both to evaluate the results convergence and to define the correct finite element method schematization. At the end, the results were compared with those obtained by classical methodology, i.e. by response to an equivalent force which was evaluated by multiply the wind pressure with the front area and defined coefficients.

The next step was to design the crane (pay load =50 t) and to study the mechanical response of the structure to the dynamic wind actions defined in the previous step.

The results (displacement) of numerical analyses show that the classical method used to study the wind actions applied on the structures overestimates those determined by power spectrum method.

Keywords: Stochastic wind loading, low profile container crane, lattice structure, finite element analysis

\section{INTRODUCTION}

The lifting equipment and in particular the crane machine are subject to different load conditions; as well as the actions induced by the pay load many other forces acting on the structures. Some of these are actions induced by moving load (lift and lower) or moving the structure or part of it [1-4], snow and ice, temperature variation, wind, earthquake [5], thermal action, actions that arise during assembly, construction or removal of the crane, etc. Some of these actions must be considered predominantly static actions, such as in the absence of movement, the dead load of the structure; other loads must be considered as dynamic actions [6]. The collapse of a crane may be induce by the wind actions, and the failure mode can be local or global buckling or overturning the crane structure. In [7] and [8], the main reason why the two cranes collapsed it was an exceptional wind loading.

This paper discusses the wind actions on the structure and in particular on a low profile container crane, by two different approaches. The first is a classical equivalent static force and the second considering the wind stochastic variability and the dynamical behavior of the crane. For this purpose, the first part of this paper reports the study conducted on a simple geometry like chimney to define a wind numerical model and study the influence by the main

Received: January 2018, Accepted: March 2018

Correspondence to: Dr Luigi Solazzi

University of Brescia, Department of Mechanical and

Industrial Engineering, Brescia, Italy

E-mail: luigi.solazzi@unibs.it variables that characterize the wind action. The second part, of this research, applies this wind model to a low profile container crane.

\section{WIND LOADING}

In general, the wind actions, forces and moments acting on the whole structure, or on its individual elements, are correlated to the size of the structure, to the maximum pressure (generally strictly dependent on the wind velocity) and to different coefficients which are correlated to the shape of the element.

It is important to underline that the stress and the displacement in the structures due to the wind actions, are directly proportional to the flexibility of the structure or element (related to the natural frequencies of the construction). For instance, the maximum value of displacement is correlated to the intrinsic damping of the material used and to the different methodologies used to join the elements together, such as welding or bolting [9-12].

Moreover, vortex streets are generated in case of downwind of the constructions and their elements, causing dynamic forces, mainly transversally to the direction of the wind.

These vortex streets may become particularly important for slender, lightweight structures with low damping capacity; subjected to alternate vortex shedding that may excite some vibration modes of the structure [13].

The study of the wind actions and consequently the effects on the structure may be performed by classical method (which is proposed also in some standards [14]). This methodology defines that the wind actions 
can be represented by means of equivalent load distributions which, statically applied to the construction or its elements, provide maximum values for the displacement and stress generated by the dynamic wind action. Therefore in this case it is possible to use the equivalent static actions, which, as stated above, incorporate both static and dynamic actions $[15,16]$.

The response, essentially in terms of displacement of the structure may be carried out by numerical analyses like finite element method.

The evaluation of the response structure to the wind excitation method, following these steps: determines the wind velocity vs time in a specific structure points, determines the drag and lift forces by $C_{D}$ and $C_{L}$ coefficients, applies these actions to finite element method and performe dynamic nuerical analyses.

The first main problem with this last methodology concerns the number of force vs time to be evaluated and implemented in the fem software (in general the number of this load vs time to be implemented in the software are limited by the software capability). The second problem concerns the processing time, which increases enormously with respect to the implementation of the first method for calculating wind action on the structures or the method based on an equivalent static force.

For this purpose, the numerical elaborations performed both for chimney and for crane consider different schematizations, i.e different load curve vs time with the object also to know how the structures subdivided in different area influence the results.

\subsection{Background theory for stochastic wind loading}

The procedure to study the stochastic wind actions consists of different steps [17-20].

First of all, it is important to evaluate the wind velocity in time in a specific point of the structure. This velocity must be multiplied by specific coefficients in order to obtain the drag and the lift forces obviously in time. These actions must be implemented in a finite element model of the structure. The results obtained are the displacement and the stress in time for the whole structure. The main equations to describe the wind actions are $[17,20]$.

Mean wind velocity $\left(V_{m}\right)$ which is function of the position point and in particular the height is:

$$
V_{m}(z)=V_{g} *\left(\frac{z}{Z_{g}}\right)^{\frac{1}{\alpha}}
$$

Shear velocity of wind field $(u)$ :

$$
u(z)=\frac{k^{*} V_{m}(z)}{\ln \left(z / z_{0}\right)}
$$

The fluctuating part of wind velocity can be evaluated by power spectrum method (point $\mathrm{j}$ ):

$$
S_{u}(\omega, z)=\frac{1}{2} \frac{1}{2 \cdot \pi} \cdot 200 \cdot u\left(z_{j}\right)^{2} \cdot \frac{z_{j}}{V_{m}\left(z_{j}\right)} .
$$

$$
\frac{1}{\left[1+50\left(\frac{|\omega| z_{j}}{2 \pi V_{m}\left(z_{j}\right)}\right)\right]^{\frac{5}{3}}}
$$

With these expressions it is possible to evaluate the coherence function between two points and the fluctuating part of the wind speed $(v)$ by formula 4 which considers a random variable in $B(\omega, j, k)$ function.

$$
v\left(j, \frac{t}{\Delta t}\right)=\operatorname{Re}\left[\sum_{k=0}^{j} \sum_{l=2}^{M} B(\omega, j, k) e^{i l p 2 \frac{\pi}{2 N}}\right]
$$

The drag and lift forces can be evaluated by:

$$
\begin{aligned}
& F_{D}=\frac{1}{2} \cdot \rho \cdot A \cdot C_{D} \cdot\left(V_{m}+v\right)^{2} \\
& F_{L}=\frac{1}{2} \cdot \rho \cdot A \cdot C_{L} \cdot\left(V_{m}+v\right)^{2}
\end{aligned}
$$

\section{METAL CHIMNEY}

The theoretical considerations reported in the previous chapter were applied to a chimney, which is a simple structure. The main object of this point is to study and validate the numerical method.

The height of chimney is $100 \mathrm{~m}$, the first portion is a conical trunk with the height equal to $34 \mathrm{~m}$, the maximum diameter is $7 \mathrm{~m}$ while the minimum diameter is $3.8 \mathrm{~m}$; the rest of the chimney is a cylindrical section with the diameter equal to $3.8 \mathrm{~m}$. The structure was composed by welding $[21,22]$.

Figure 1 shows the geometry and the thickness of the steel sheet of the chimney.

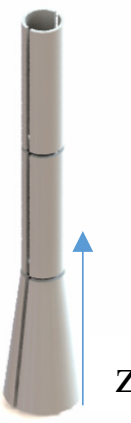

\begin{tabular}{|c|c|c|}
\hline Z initial[m] & Z final $[\mathrm{m}]$ & Thickness $[\mathrm{mm}]$ \\
\hline 0 & 27.2 & 18 \\
\hline 27.2 & 40.0 & 16 \\
\hline 40.0 & 52.0 & 14 \\
\hline 52.0 & 64.0 & 12 \\
\hline 64.0 & 76.0 & 10 \\
\hline 76.0 & 100.0 & 8 \\
\hline
\end{tabular}

Z

Figure 1. Geometry of chimney.

\subsection{Study the chimney subject to equivalent static action}

The chimney was located in a flat area away from buildings that can reduce the wind actions.

The aerodynamic force due to the wind action is given by the product of the kinetic pressure (variable with the height) with the section diameter and the force coefficient [23]. The main parameters are: $V_{g}=55 \mathrm{~m} / \mathrm{s}$; $Z_{g}=15 \mathrm{~m} ; \alpha=1 / 7 ; C_{D}=0.2$ and $C_{L}=0.1$.

The numerical analyses were performed by finite element method [24] with Autodesk Simulation ${ }^{\circledR}$ software. The fem model was composed about 20000 
quadratic plate element. Figure 2 shows the force values (at different height of chimney).

\begin{tabular}{|c|c|}
\hline$Z[\mathrm{~m}]$ & $\mathrm{F}[\mathrm{N}]$ \\
\hline 10 & 31040 \\
\hline 20 & 31970 \\
\hline 30 & 29030 \\
\hline 40 & 28340 \\
\hline 50 & 29910 \\
\hline 60 & 31210 \\
\hline 70 & 32330 \\
\hline 80 & 33310 \\
\hline 90 & 34190 \\
\hline 100 & 34980 \\
\hline
\end{tabular}

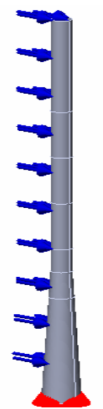

Figure 2. Force values and fem model for numerical analyses on chimney.

The numerical result is shown in figure 3.
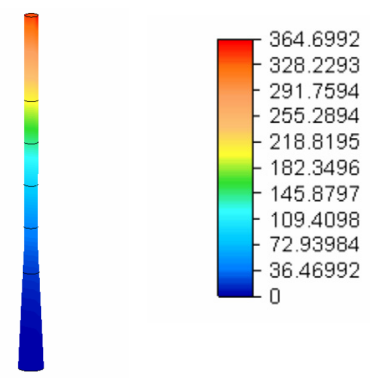

Figure 3. Displacement result [mm] from numerical elaboration.

\subsection{Modal analyses}

As mentioned in the brief theoretical background reported in the previous paragraph it is fundamental to determine the dynamical behavior of the structure. Figure 4 shows the chimney displacement corresponding to the first seven vibration modes.

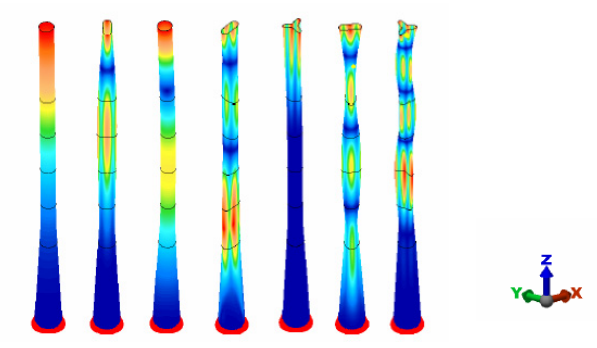

Figure 4. Deformation of chimney for first seven vibration modes: a) $=0.740 \mathrm{~Hz}$; b) $=1.58 \mathrm{~Hz}$; c) $=2.52 \mathrm{~Hz}$; d) $=3.21 \mathrm{~Hz}$; e) $=3.59 \mathrm{~Hz} ; \mathrm{f})=4.31 \mathrm{~Hz}$ and $\mathrm{g}$ ) $=5.03 \mathrm{~Hz}$.

The first and the third vibration mode are the most important because they involve the maximum values of mass participation factors; and in particular for the first mode this value is about a $36.1 \%$ while for the third mode, this value is about $22.2 \%$. The mass engaged in the other natural frequencies is practically negligible.

\subsection{First partition into chimney areas}

Figure 5 shows the chimney first partition. It is composed of two points on three diameters. The first diameter is at the top of the chimney, the second in the middle of the cylindrical zone and the third at the top of the conical zone. Figure 5 reports the point number and its coordinates.
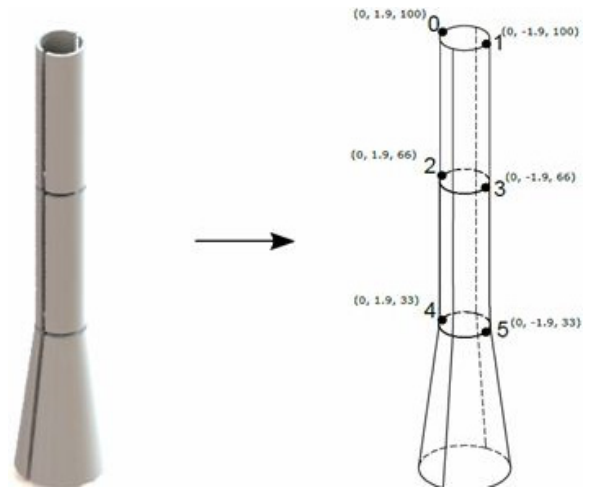

Figure 5. First partition of chimney.

Figure 6 shows the velocity versus time for the first four points; while figure 7 shows the drag and lift forces for the same points.
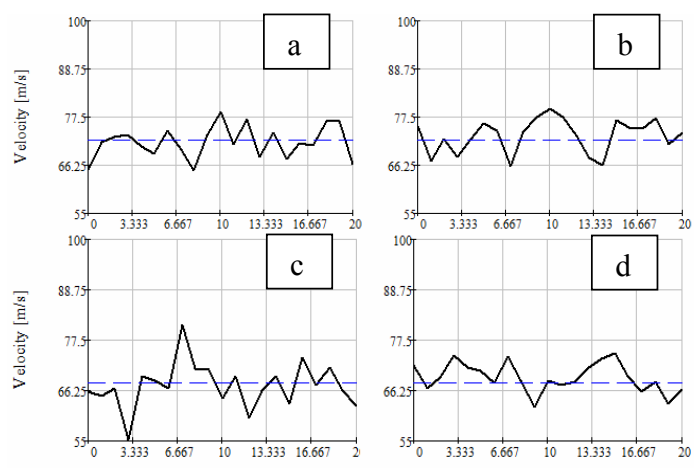

Figure 6. Wind velocity $[\mathrm{m} / \mathrm{s}]$ vs time [s], blue=mean value; a) point=0; b) point=1; c) point=2 and d) point=3.
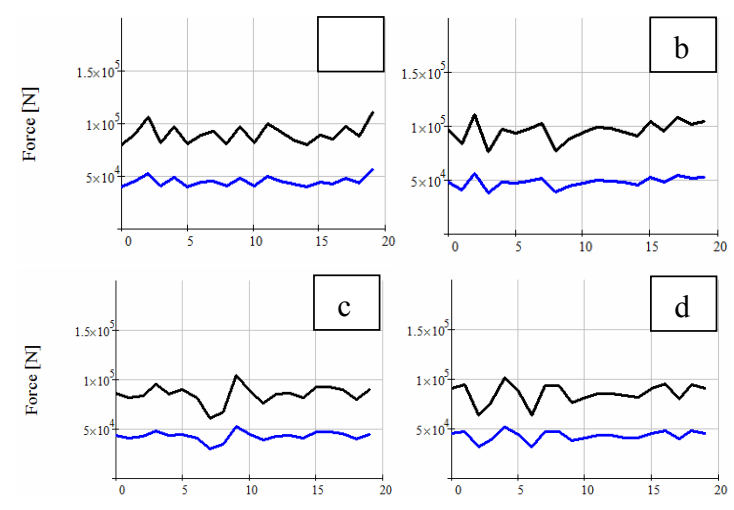

Figure 7. Drag and lift force [N] vs time [s], black =drag force, blue=lift force; a) point $=0$; b) point $=1$; c) point $=2$ and d) point $=3$.

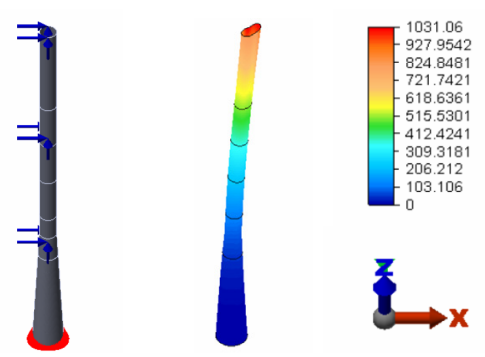

Figure 8. Fem model and maximum displacement in the chimney. 
Figure 8 shows the fem model and the displacement result, while figure 9 shows the displacement in time for the point at the top of the chimney.

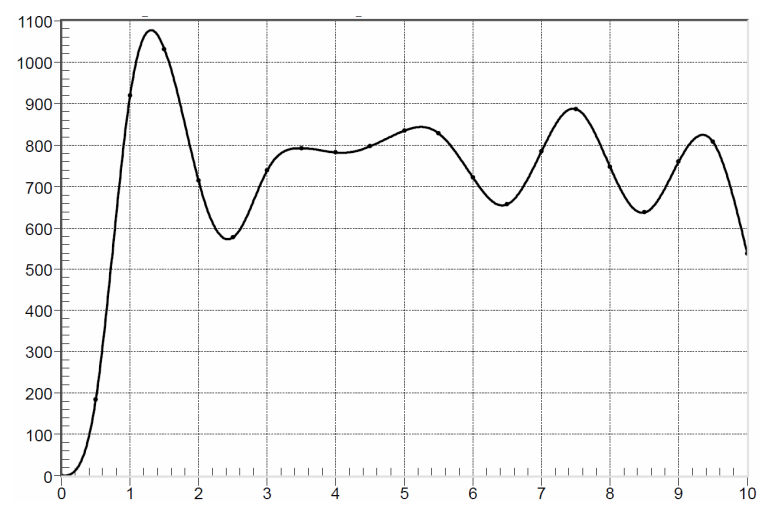

Figure 9. Displacement [mm] vs time [s] for a point at the top of the chimney.

\subsection{Chimney with different partition areas}

With the object to study how the subdivision area influences the maximum displacement result for chimney (i.e. the number of load curves applied), the numerical procedure described above was applied to different partition. These subdivisions areas are shown in the figure 10. The results obtained are reported in figure 11 for points at the top of the chimney $(100 \mathrm{~m})$ and figure 12 for points at $75 \mathrm{~m}$.

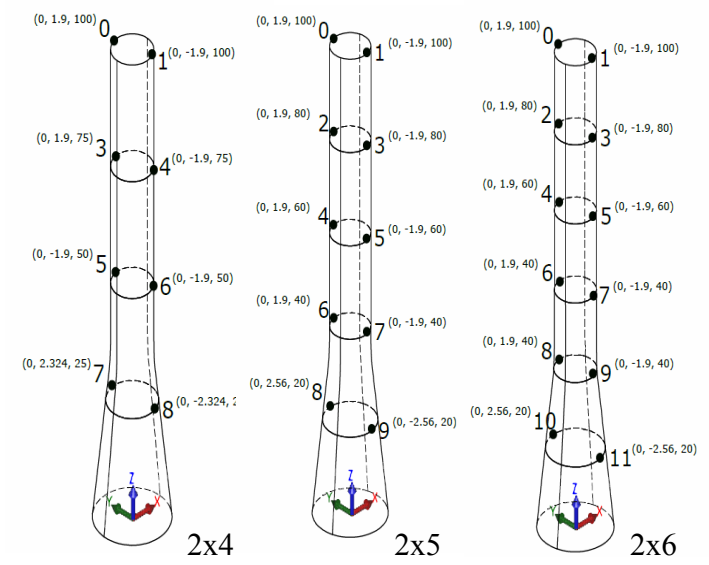

Figure 10_a. Chimney subdivided into different areas.

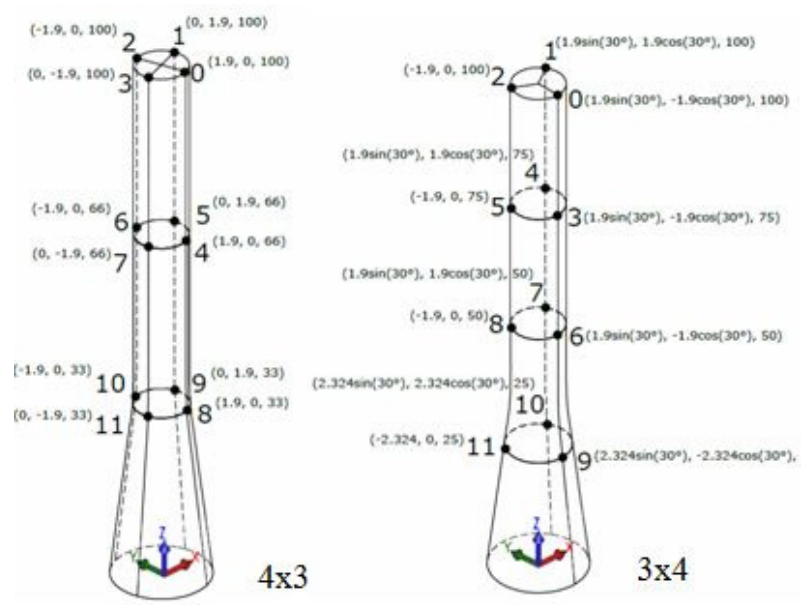

Figure 10_b. Chimney subdivided into different areas.

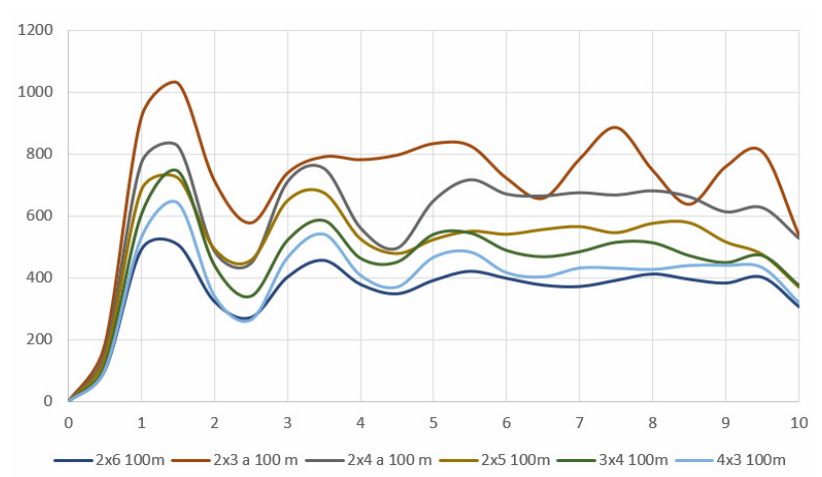

Figure 11. Chimney displacement for a point at the top of structure for different partition.

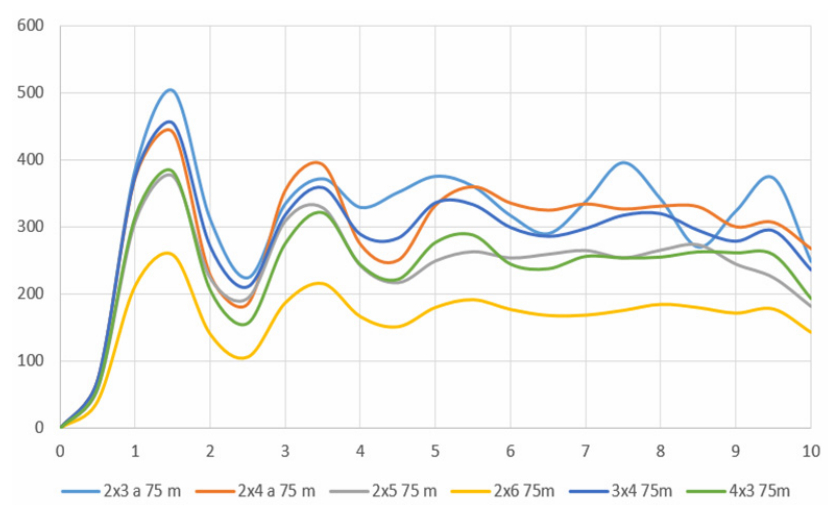

Figure 12. Chimney displacement for a point at $75 \mathrm{~m}$ for different subdivisions.

The displacement values change with the partition adopted, the trend that can be observed both for the point positioned at the end of chimney and at different height. The displacement values in time are within a specific range (about $\pm 30 \%$ of mean value). The partitions with high number of points show very similar displacement values and more near the mean value considering the different schematizations adopted.

\subsection{Effect of different length time of simulation}

In order to better understand the numerical simulation results, the last parameter studies concern the duration time of the wind action applied to the chimney. Figure 13 shows the displacement results for $60 \mathrm{~s}$ respect to 10 $\mathrm{s}$ simulated in the previous paragraphs. This parameter is very important because correlated with this parameter is the computational time for numerical analyses and in particular the c.p.u. time for numerical analyses.

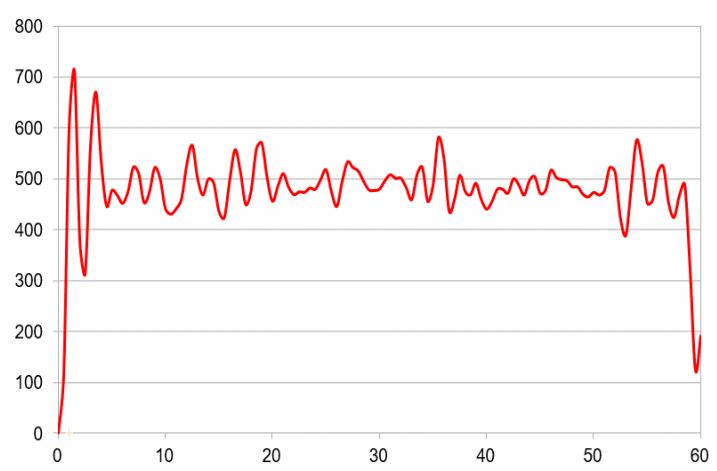

Figure 13. Chimney displacement for point at the top of chimney (partition 3x4). 
If we compare figure 13 with figure 11 it is possible to observe very similar displacement values both for maximum value and for mean value. In particular, it is possible to underline that the mean value (over about 5 seconds) does not change.

\section{LOW PROFILE CONTAINER CRANE}

The dynamic action development in the previous chapter was applied to a low profile container crane.

The main characteristics of this machine are:

- $\quad$ Pay load $=50$ t;

- Lifting velocity (without load) $=85 \mathrm{~m} / \mathrm{min}$;

- Lifting velocity (with load) $=35 \mathrm{~m} / \mathrm{min}$;

- Maximum height (under spreader) $=30 \mathrm{~m}$;

- Overall height $=55 \mathrm{~m}$;

- $\quad$ Boom length $=80 \mathrm{~m}$.

Figure 14 shows the final design of this machine and the displacement [mm].

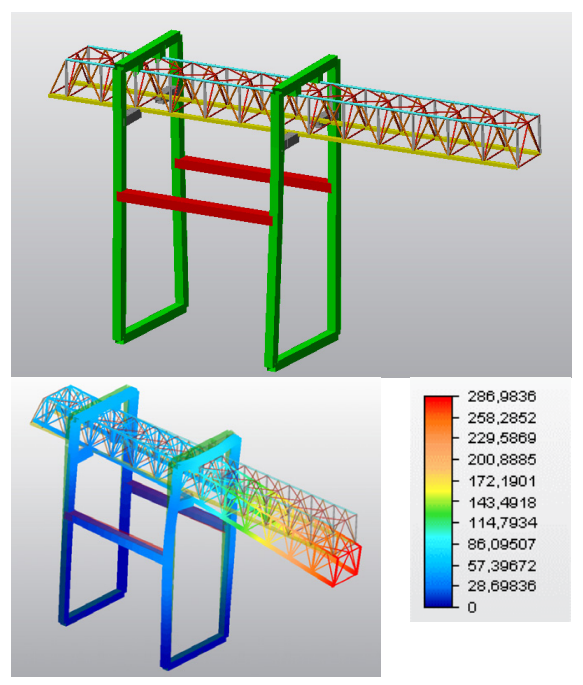

Figure 14. Low profile container crane: solid model ant the displacement [mm] due both the dead load and payload.

The main parameters used for evaluating the wind action are: $V_{g}=75 \mathrm{~m} / \mathrm{s} ; Z_{g}=20 \mathrm{~m} ; \alpha=1 / 7 ; C_{D}=1.3$ and $C_{L}=0.1$.

The numerical analyses were carried out by finite element method with the same software used for the chimney. The FEM model was composed of about 40.000 quadratic beam elements.

The boundary conditions implemented at the base of the crane are hinges.

The maximum displacement due both dead load and payload is about $300 \mathrm{~mm}$ while the value acquired applying the equivalent static force method (for wind loading) is about $2600 \mathrm{~mm}$.

\subsection{Modal analyses}

Figure 16 shows the first six vibration modes for crane, while table 2 shows the percentage of mass participation factor.

In this table it is important to observe that the first four frequencies are the most important. The first two regard the boom deformation, while the other two also cover the portal deformation.
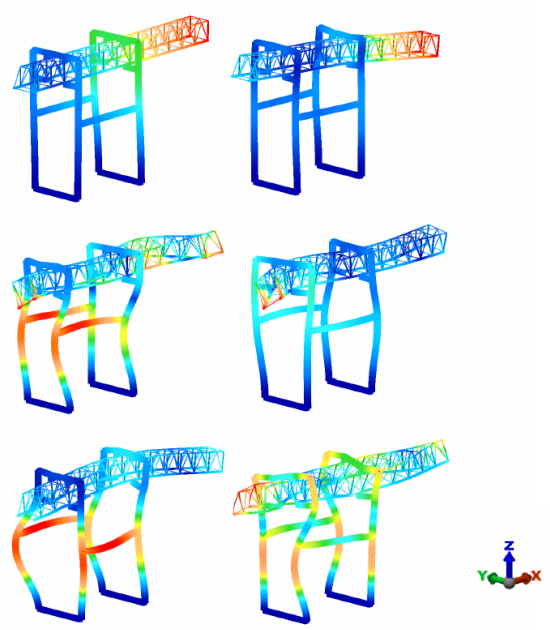

Figure 16. Deformation corresponding to the six vibration mode of crane.

Table 2. Natural frequencies [Hz] and [\%] of mass participation factor.

\begin{tabular}{|c|c|c|c|c|c|c|}
\hline $\begin{array}{c}\text { fi }[\mathrm{Hz}] / \\
\text { \%Mass }\end{array}$ & 0.29 & 0.42 & 0.46 & 1.63 & 1.82 & 2.99 \\
\hline $\mathrm{X}$ & 0 & 0 & 96.4 & 0.2 & 0 & 0 \\
\hline $\mathrm{Y}$ & 52.5 & 43.8 & 0 & 0 & 0.01 & 0.01 \\
\hline $\mathrm{Z}$ & 0 & 0 & 0.02 & 20.6 & 0 & 0 \\
\hline
\end{tabular}

\subsection{Crane partition}

The procedure used for the crane was the same used for the chimney. In particular, figure 17 shows the displacement in time at the end of the boom due to different partition i.e. points number.

In particular, figure 18 shows the crane subdivision areas and the finale finite element model implemented. The maximum points number adopted (compatibly with the computer performance) are 60 points. The results reported correspond to this schematization.

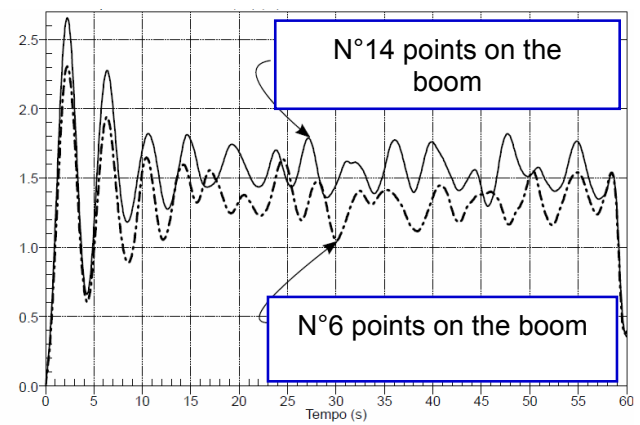

Figure 17. Displacement in time, for the boom with two different schematizations.

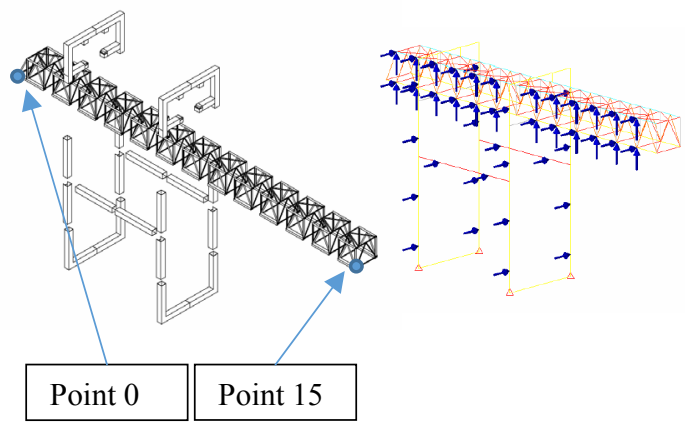

Figure 18. Area subdivision for crane and fem model. 
Figure 19 and figure 20 show the wind velocity and the drag and lifting force applied to two different points of crane.

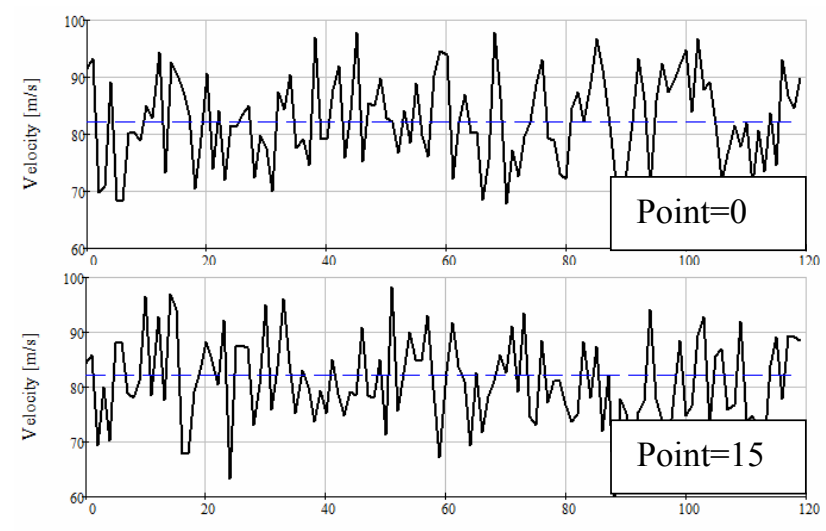

Figure 19. Wind velocity $[\mathrm{m} / \mathrm{s}]$ vs time [s] for point 0 (at the rear of the boom) and point 15 (at the front of the boom), blue=mean value.

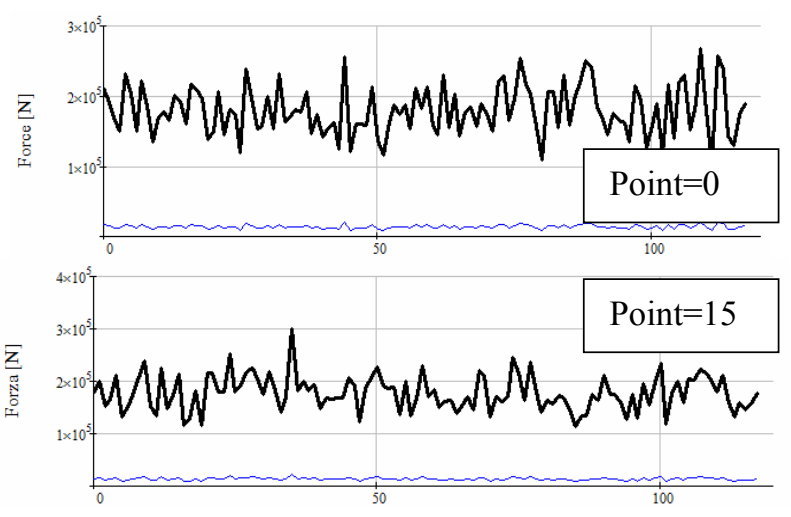

Figure 20. Drag and lift force [N] vs time [s] for point Oand point 15.

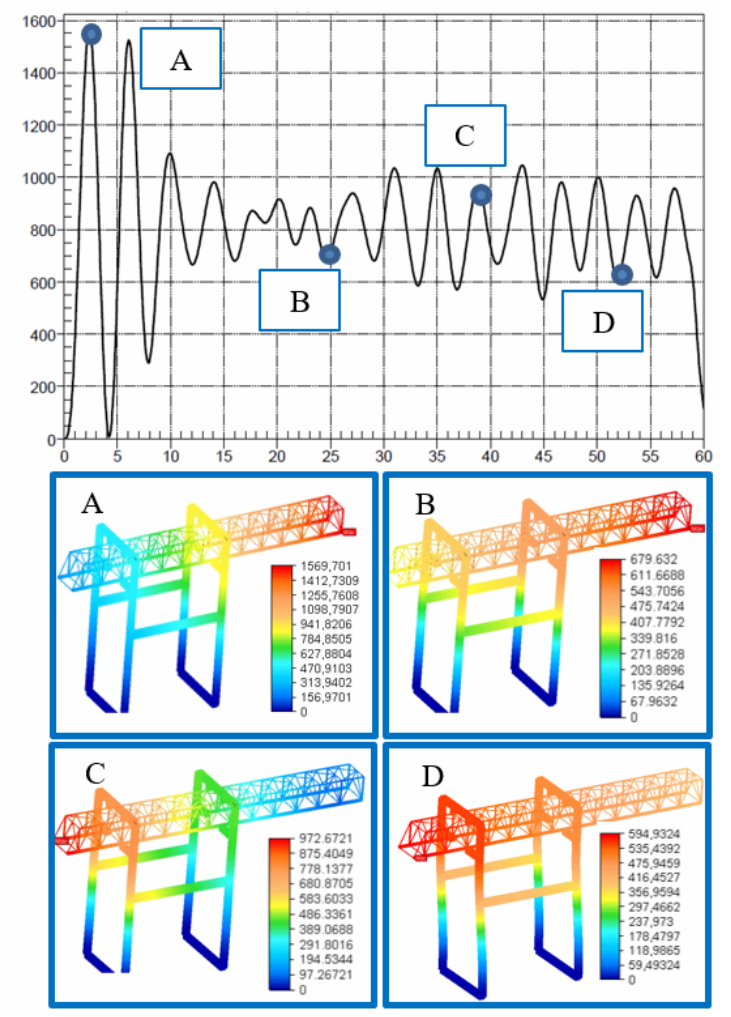

Figure 21. Maximum displacement [mm].
Figure 21 shows the maximum displacement trend and some images acquired from numerical analyses. From these images it is possible to underline that the crane movement in time is complex, in fact it is possible to observe that in some time the crane is subjected not only to translate movement but also to twist movement.

\section{RESULTS}

The numerical analyses performed by the stochastic wind actions method is more complex than the classical equivalent static force method. The main parameter that influences the numerical results is the number of partitions, which the structure was divided into, i.e. the number of points to which the force vs time induced by wind was applied. For the chimney and for the crane, the number of points to obtain a stable solution are about 15 and 30 respectively. Both for the chimney and the crane, the maximum displacement obtained by the static equivalent force method is bigger than the ones obtained by stochastic wind loading method.

\section{CONCLUSION}

This paper reports a specific numerical research carried out on the actions induced by the wind on two different structures. The first is a very high chimney and the second is a classical very big low profile container crane. The objects of this study are different and in particular define the power spectra for wind actions, define the correct finite element model and study how the different schematization influences the results. The last target is to compare the result (in terms of displacement) obtained considering variable wind actions with those determined by classical or standardized method. For this last point of view it is important to underline that both for the chimney and the crane the standard method overestimates the actions applied to the structures, the reason for this is that the research is still in progress to deeply understand if this trend is confirmed also for different structures or different lifting equipment; in particular how the dynamic behavior of the structure (like natural frequencies) influences the disagreement between the results achieved by the equivalent static force and those obtained by dynamic method. The results of this research are therefore very important because they allow to design more secure and reliable structures.

\section{REFERENCES}

[1] Gašić, V. and Zrnić, N.: Considerations of various moving load models in structural dynamics of large gantry cranes, FME Transactions, Vol 41, pp. 311316, 2013.

[2] Zrnić, N., Gašić, V., Bošnjak, S. and or ević, M.: Moving loads in structural dynamics of crane: brid-ging the gap between theoretical and practical rese-arch, FME Transactions, Vol 41, pp.291-297, 2013.

[3] Solazzi, L., Incerti, G. and Petrogalli, C.:Estimation of the dynamic effect in the lifting opertions of a boom crane, in ECMS 2014,27-30.05.2014, Brescia, pp.309-315. 
[4] L.Solazzi, N. Zrnić, Design of a high capacity derrick crane considering the effects induced by load application and release, Journal of Applied Engineering Science, Vol. 15, Issue 1, pp 15-24, 2017.

[5] Solazzi, L.: Ship to shore crane subject to earthquake, Procedia Engineering, Vol. 10, pp. 2690-2695, 2011.

[6] L. Solazzi, Experimental and analytical study on elevating working platform; Procedia Engineering, Vol. 199,pp. 2597-2602,2017.

[7] McCarthy, P., Soderberg, E. and Dix, A.; Wind damage to dockside cranes: recent failures and recomandations, in TCLEE 2009, 28-06/0207.2009, Oakland, California.

[8] Dong, H.K., Byung, C.O., Sang, H. H., Jae, S.S., In, S.C., Man, S.S. and Ji, S.J.; Calllapse of container cranes at busan ports under typhoon maemi, in Proceedings of the 14th international offshore and polar engineering conference, 2328.05.2004, Toulon, France, ISBN 1-880653-62-1, ISSN 1098-6189.

[9] Simiu, E. and Scanlan, R.H.: Wind effects on structures: Fundamentals and applications to design, 3rd Edition, John Wiley \& Sons, New York, 1996.

[10] Dyrbye, C. and Ole Hansen, S.: Wind Loads on Structures, Wiley, New York 1997.

[11] Davenport, A.G., Riera, J.D., Wind effects on building and structures, Taylor \& Francis, 1998.

[12] Blaise, N., Canor, T. and Denoel. V.: Equivalent static wind loads for structures with nonproportional damping, in Rasd 2013 11th International conference on Recent and Advances in Structural Dynamics 01-03.07.2013, Pisa (Italy), Paper 828.

[13] Tamura Y., Karrem A., Advances structural wind engineering, Springer, 2013.

[14] European Committee for Standardisation, Eurocode 1: Basis of design and actions on Structures, Brussels, ENV 1991-2-1, 1995.

[15] Sang-Joon, L. and Jong-Hoon, K.: Wind load on a container crane located in atmospheric boundary layers, J. of Wind Engineering and Industrial Aerodynamics, Vol. 96, pp. 193-208, 2008.

[16] Bošnjak, S., Zrnić, N. and Dragović, B.:Dynamic response of mobile elevating work platform under wind excitation, J. of Mechanical Engineering, Vol. 55, pp.104-113, 2009.

[17] Sourav, G. and Samit, R.: Probabilistic assessment of container crane under wind loading, in: Proceedings of the International Symposium on engineering under uncertainty: safety assessment and management (ISEUSAM 2012), DOI
10.1007/978-81-322-0757-3_72, Springer India 2013.

[18] Castino, F., Festa, R., Ratto, C.F. Stochastic modelling of wind velocities time series. Journal of wind engineering and industrial aerodynamics, 1998, 74-76, 141-151.

[19] Hasen, S.O., Krenk, S. Dynamic along wind response of simple structures. Journal of wind engineering and industrial aerodynamics, 1999, 82, 147-171.

[20] Ambrosini, R.D., Riera, J.D., Danesi, R.F. Analysis of structures subjected to random wind loading by simulation in the frequency domain. Probabilistic engineering mechanics, 2002, 17, 233-239.

[21] Kawecki, J., Zuranski, J.A. Cross-wind vibrations of steel chimneys - A new case history. Journal of wind engineering and industrial aerodynamics, 2007, 95, 1166-1175.

[22] Consiglio Nazionale delle Ricerche (Ita) CNR-DT 207/2008_19/02/2009.

[23] Scarabino, A., Mara ón Di Leo, J., Delnero, J.S., Bacchi, F.: Drag coefficients and strouhal numbers of a port crane boom girder section, , J. of Wind Engineering and Industrial Aerodynamics, Vol. 93, pp. 451-460, 2005.

[24] Chang-koon, C., Won-jin, Y. Finite element techniques for wind engineering. Journal of wind engineering and industrial aerodynamics, 1999, 81, 83-95.

\section{СТОХАСТИЧКО ОПТЕРЕЪЕЊЕ ВЕТРОМ КОД КОНТЕЈНЕРСКЕ ДИЗАЛИЦЕ}

\section{Л. Солаци}

Истражује се механичко понашање контејнерске дизалице под дејством променљивог оптерећења ветром. Прво се проучава и дефинише дејство ветра. Симулација стохастичког оптерећења ветром се врши методом спектра снаге. Прелиминарне анализе су извршене на димњаку (висине 100 м) због његове једноставне геометрије. Примењене су различите шеме за евалуацију конвергенције резултата и дефинисање шеме адекватног ФЕМ метода. Резултати су упоређени са резултатима добијеним класичном методологијом, тј. одговором на еквивалентну силу израчунату множењем притиска ветра са фронталном површином и дефинисаним коефицијентима. Следећи корак је пројектовање дизалице (корисно оптерећење $=50$ t) и утврђивање механичког одговора конструкције на динамичка дејства ветра дефинисана у претходној фази. Резултати (помераја) нумеричке анализе показују да се применом класичне методе у проучавању дејства ветра на конструкцију добијају превисоки резултати у односу на дејства одређена методом спектра снаге. 